DOI: $10.19195 / 0137-1134.114 .15$

\author{
ALEKSANDRA SZADOK-BRATUŃ \\ Uniwersytet Wrocławski \\ aleksandra.szadok-bratun@uwr.edu.pl
}

\title{
MINIREFLEKSJE NAD MAKSIKWESTIAMI, CZYLI O AKSJOLOGICZNYCH ASPEKTACH PRAWORZĄDNOŚCI ${ }^{1}$
}

\begin{abstract}
Abstrakt: Część pierwsza szkicu ma za cel ukazać praworządność jako konstrukt filozoficznoprawny z uwzględnieniem dychotomicznych podziałów. Zakres dyskursu sprowadzony został do dwóch płaszczyzn-problemów. Pierwsza - rozumienie desygnatów opozycyjnych terminów eunomiaisonomia. Druga - selektywne zaprezentowanie przeciwstawnych typów praworządności w kluczu korelacji pojęciowej: praworządność-legalność, praworządność podmiotowa-przedmiotowa, praworządność formalna-materialna.

Część druga opracowania to próba spojrzenia na praworządność w optyce dwumianu aksjologicznoprawnego. Analogicznie do pierwszej części publikacji zachowany został swoisty symetryzm metodologiczny. Analizy przeprowadzono w dwóch obszarach poznawczych. Pierwszy to zdefiniowanie praworządności materialnej rozumianej inkluzywnie, łącznie z atrybutami praworządności formalnej. Drugi to próba wyselekcjonowania zasad-wartości, z jakich powinien składać się współcześnie epikurejski tetrapharmakon terapeutyczny w odniesieniu do praworządności materialnej.
\end{abstract}

Słowa kluczowe: aksjologia prawa, praworządność, godność, wolność, równość, sprawiedliwość, wartość

\section{PRAWORZĄDNOŚĆ JAKO DUALNY KONSTRUKT FILOZOFICZNOPRAWNY}

\section{TERMINOLOGIA}

Etymologicznie rzecz biorąc, pojęcie praworządności zakorzenione jest w starożytnej myśli polityczno-prawnej, w greckim terminie eunomia (łaciński synonim: legalitas) złożonym z dwóch członów: eu - dobry i nomos - prawo, co zwykło się przekładać na sprawiedliwy przydział, dobre zarządzanie, przestrzeganie prawa bądź dobre prawo. Pierwotne znaczenie tego wyrazu wywodzi

1 Sformułowanie zawarte w tytule publikacji: Minirefleksje nad maksikwestiami zostało zapożyczone od L. Kołakowskiego z książki Mini wykłady o maxi sprawach, Kraków 2003. 
się z mitologii greckiej. Eunomia — Praworządność — to imię jednej z córek (Hor, bogiń uosabiających również trzy pory roku) Temidy i Zeusa, strzegącej wespół z siostrami, Dike — Sprawiedliwość i Ejrene - Pokój, ładu społecznego i porządku natury ${ }^{2}$. Już w ówczesnych czasach terminem tym wyrażano niezadowolenie wobec władzy naruszającej zasadę rządów prawa, określaną mianem isonomi. W dosłownym tłumaczeniu wyraz ów oznaczał „równość prawa” (isos — równy i nomos — prawo), natomiast jego ewoluująca semantyka poszerzyła zakres treściowy pierwowzoru o kolejne desygnaty, takie jak: „równouprawnienie”, „demokracja” czy też „rządy prawa”3. Cnota praworządności, rozumiana jako sprawiedliwość współdzielcza usprawniająca do redystrybucji dobra wspólnego ${ }^{4}$, wypracowana w tradycji platońsko-arystotelesowskiej ${ }^{5}$, niesie w sobie po dziś dzień wraz z dziejową transformacją ustrojów państw najgłębsze refleksy antycznej myśli aksjologicznoprawnej.

\section{TYPOLOGIA PRAWORZĄDNOŚCI}

We współczesnym polskim prawoznawstwie, zwłaszcza konstytucjonalizmie, daje się zauważyć tendencję do dychotomicznego ujmowania praworządności, uwzględniającą jako fundamentum divisionis chociażby takie oto kryteria: pojęciowy (a)symetryzm (praworządność-legalność), zakres (podmiot-przedmiot) i zasięg (formalny-materialny). Konotacja nazwy ,praworządność” już od starożytności, a zwłaszcza od jurysprudencji rzymskiej, odczytywana jest w kluczu korelacji pojęciowej praworządność-legalność z powodu zbieżności semantycznej owych terminów. Treściowa konstrukcja art. 7 Konstytucji $\mathrm{RP}^{6}$ pozwala wyodręb-

2 Zob. Mała encyklopedia kultury antycznej, red. Z. Piszczek, Warszawa 1968, s. 384; W. Kopaliński, Hory, [hasło w:] idem, Stownik mitów i tradycji kultury, Warszawa 1991, s. 386-387; E. Łętowska, K. Pawłowski, O prawie i o mitach, Warszawa 2013, s. 33.

3 Zob. Mata encyklopedia kultury antycznej, s. 400.

4 Cnotę sprawiedliwości współdzielczej J. Woroniecki nazywa praworządnością, czyli ,stałą skłonnością czy też sprawnością woli, aby we wszystkim, co się poczyna, mieć zawsze wzgląd na dobro ogółu, o którym stanowią prawa, aby się więc we wszystkim rządzić prawem. Między cnotami moralnymi sprawiedliwość współdzielcza, czyli praworządność, zajmuje pierwsze miejsce. [...] ma podporządkować wszystko naczelnemu celowi życia doczesnego, jakim jest dobro społeczeństwa, w którym człowiek żyje", idem, Katolicka etyka wychowawcza, t. 1, Lublin 2013, s. 290-291.

5 Platon w swoich kunsztownych dialogach — i ze względu na formę literacką, i sztukę rozumowania - nieustannie prowadził dysputy o państwie idealnym rządzonym przez filozofów i państwie realnym, sprawiedliwym i praworządnym rządzonym przez dobre prawa. Zob. zwłaszcza dialogi polityczne ukazujące owe modele państwa zamieszczone w Państwo. Prawa (VII ksiag), przeł. W. Witwicki, Kęty 1998. Również Arystoteles w działach zwanych pismami szkolnymi, wykładami z filozofii praktycznej, do których należą Etyka nikomachejska (przeł. D. Gromska, Warszawa 2007) i Polityka (przeł. L. Piotrowicz, Warszawa 2006), jawi się jako filozof prawoznawca dogłębnie analizujący etyczne atrybuty Praworządności.

6 Konstytucja Rzeczypospolitej Polskiej z dnia 2 kwietnia 1997 r. (Dz.U. Nr 78, poz. 483 z późn. zm.; dalej: Konstytucja RP). 
nić ze względu na jej pojemny desygnat dwie zasady ustrojowe — praworządność i legalizm ${ }^{7}$. Pierwsza wyraża się w ustawowej formule działania organów władzy publicznej „w granicach prawa”, w czym zbliża się do greckiego sensu tego wyrażenia, czyli przestrzegania prawa. Druga natomiast, uwzględniająca nakaz działania władzy państwowej na ,podstawie prawa”, osadzona jest w etymologicznej diadzie bliskoznacznych terminów łacińskich: legalis - ustawowy, prawny, zgodny z ustawą/prawem i legitimus - uprawomocniony, prawowity, odpowiedni, słuszny; urobionych od zwrotu lex - ustawa, przepis ustawy/prawa, norma, reguła $^{8}$. Upraszczając, można przyjąć, że wykładnia lingwistyczno-semantyczna przytoczonego przepisu podzieliła konstytucjonalistów na dwie frakcje. Dualiści, reprezentujący stanowisko większościowe, wyróżnione zasady najczęściej traktują jako dopełniające się człony koniunkcji, uznając je za integralne komponenty zasady demokratycznego państwa prawnego ${ }^{9}$. Moniści natomiast dostrzegają w przepisie art. 7 jedynie zasadę legalizmu, która w ich rozumieniu absorbuje zasadę praworządności (ujęcie szerokie) lub separuje, zwłaszcza jej walor materialnoprawny osadzony w art. 2 Konstytucji RP (ujęcie wąskie) ${ }^{10}$.

W pojmowaniu praworządności, przyjmując za kryterium podziału zakres treściowy, zwykło się wyróżniać dwa aspekty — podmiotowy i przedmiotowy. Z perspektywy polskiej myśli polityczno-prawnej XX i XXI wieku koncepcje praworządności podmiotowej układają się dwubiegunowo. Z jednej strony znajduje się ewoluująca koncepcja związana z odcieniami metaprawnej doktryny państwa socjalistycznego ${ }^{11}$, która sensu largo głosiła obowiązek ścisłego przestrzegania prawa pozytywnego zarówno przez rządzących, jak i rządzonych, a sensu stricto

7 W ustawodawstwie podkonstytucyjnym można zauważyć odejście od komplementarnego i korelacyjnego ujmowania ustrojowych zasad praworządność - legalność na rzecz ich separatystycznej konstrukcji normatywnej. Kapitalnym przykładem jest ustawa z dnia 14 czerwca $1960 \mathrm{r}$. — Kodeks postępowania administracyjnego (Dz.U. z 2017 r. poz. 1257) statuująca rozdzielnie wartości legalizmu: „Organy administracji publicznej działają na podstawie prawa” (art. 6) od wartości praworządności: „W toku postępowania organy administracji stoją na straży praworządności” (art. 7).

8 M. Kuryłowicz, legalis, legitimus, lex, [hasła w:] idem, Stownik terminów, zwrotów i sentencji prawniczych łacińskich oraz pochodzenia łacińskiego, Kraków 2002, s. 54-55; W. Kopaliński, legislacja, [hasło w:] idem, Stownik wyrazów obcych i zwrotów obcojęzycznych, Warszawa 1967, s. 298-299; legitimus, [hasło w:] Słownik tacińsko-polski, oprac. K. Kumaniecki, Warszawa 1973, s. 289.

9 Zob. W. Sokolewicz, M. Zubik, Komentarz do art. 7, [w:] Konstytucja Rzeczypospolitej Polskiej. Komentarz, red. L. Garlicki, M. Zubik, t. 1, Warszawa 2016, s. 240-241; P. Sarnecki, Rzeczpospolita Polska państwem prawnym, [w:] Prawo konstytucyjne Rzeczpospolitej Polskiej, red. P. Sarnecki, Warszawa 2014, s. 73.

10 Zob. T. Górzyńska, Zasada praworządności i legalności, [w:] Zasady podstawowe polskiej konstytucji, red. W. Sokolewicz, Warszawa 1998, s. 93, 101-105.

11 Charakterystykę publikacji prawniczych o praworządności w latach 1945-1989 zaprezentował J. Nowacki w opracowaniu Rzady prawa. Dwa problemy, Katowice 1995, s. 20 n. 
ograniczyła adresatów praworządności do organów państwa ${ }^{12}$. Z drugiej — koncepcja demokracji neoliberalnej ${ }^{13}$ wiążąca praworządność wyłącznie z podmiotami dysponującymi atrybutem władztwa w sferze ustawodawczej, wykonawczej i sądowniczej. Pod rządami obowiązującej ustawy zasadniczej praworządność podmiotowa interpretowana jest $\mathrm{w}$ doktrynie i orzecznictwie sensu largissimo ${ }^{14}$. Konotacja treściowa wyrażenia „organy władzy publicznej” obejmuje swym zakresem nie tylko organy państwa i samorządu terytorialnego w sensie ustrojowym, czyli organy zdefiniowane ustawowo, lecz także organy w sensie funkcjonalnym, wykonujące zadania publiczne wskutek powierzenia lub przekazania im tych zadań (kompetencji) przez organy ustrojowe ma mocy przepisu ustawowego ${ }^{15}$.

Współczesne rozumienie praworządności przedmiotowej rozwija się pod wpływem dwóch kultur prawniczych — anglosaskiej jurysprudencji i kontynentalnej filozofii prawa. W pierwszej praworządność pojmowano negatywnie jako wolność (obronę) obywateli od arbitralności samowolnej władzy, w drugiej — pozytywnie jako zobowiązanie organów państwa do działania zgodnego z prawem i tym sposobem kształtowania świadomości prawnej obywateli, tworzenia obyczaju prawnego ${ }^{16}$. „Praworządność”, termin polskiego języka prawnego i prawniczego, w tradycji anglosaskiej wyraża formuła „rządy prawa” (rule of law), a w tradycji kontynentalnej, zwłaszcza niemieckiej i francuskiej, przybiera postać „państwa prawnego" (Rechtsstaat, L'Etat de droit) ${ }^{17}$. Pojęcia te mimo swych odmienności

12 Więcej o polemice toczącej się wokół adresatów praworządności czasu przedtransformacyjnego zob. J. Nowacki, Praworzadność. Wybrane problemy teoretyczne, Warszawa 1977, s. 7-64.

13 Ideę demokracji liberalnej w kontrapunkcie do demokracji dogmatycznej wprowadził i rozwinął F. Hayek w książce The Constitutinon of Liberty, London 1976, s. 107 n. (wyd. polskie Konstytucja wolności, Warszawa 2006). Ta ostatnia, w jego ocenie, przesadnie apologizuje rolę większości parlamentarnej, a druga sprzeciwia się dyktaturze większości parlamentarnej, opowiadając się za prymatem praw człowieka.

14 Zob. W. Sokolewicz, M. Zubik, op. cit., s. 245-246; T. Górzyńska, op. cit., s. 96-98; P. Tuleja, Komentarz do art. 7 uwagi 8-10, [w:] Konstytucja RP, t. 1. Komentarz do art. 1-86, red. M. Safjan, L. Bosek, Warszawa 2016.

15 Sporne kwestie terminologiczne związane z rozumieniem pojęć typu: „organ państwa”, „organ władzy publicznej” czy też „organ administracji” przedstawia wiele publikacji z obszaru prawa publicznego, zwłaszcza konstytucyjnego i administracyjnego. Tytułem przykładu można wymienić niektóre z nich: L. Garlicki, Polskie prawo konstytucyjne. Zarys wykładu, Warszawa 2014; B. Banaszak, Prawo konstytucyjne, Warszawa 2017; J. Langrod, Instytucje prawa administracyjnego. Zarys części ogólnej, Kraków 2003, reprint; Prawo administracyjne, red. J. Boć, Wrocław 2010; J. Zimmermann, Prawo administracyjne, Warszawa 2016.

16 Zob. K. Wroczyński, Praworządność, [w:] Powszechna encyklopedia filozofii, red. A. Maryniarczyk, t. 8, Lublin 2007, s. 468.

17 Por. J. Nowacki, Rządy prawa, s. 15-28. Rozróżnienie w prawoznawstwie owych trzech pojęć to zarazem rozróżnienie trzech płaszczyzn badawczych, z których każda posiada własny aparat krytyczny, literaturę i tradycję kulturową. Stąd też mamy trzy obszary geograficzne z dominacją jednego z terminów: ,praworządność”, termin teorii prawa - Europa Wschodnia, ,państwo prawne”, termin filozofii prawa - Europa Zachodnia i „rządy prawa”, termin jurysprudencji — kraje anglosaskie. 
w ,genotypie” filozoficznym, jurydycznym i polityczno-społecznym współkształtowały europejski model demokratycznego państwa prawnego, opierając go na wartościach konstytucyjnych, legitymizujących porządek prawny. W niemieckiej koncepcji państwa prawnego, najsilniej oddziałującej na kształt Konstytucji RP, już w pierwowzorze sformułowanym przez R. von Mohla rozróżniano aspekty materialne i formalne państwa prawnego ${ }^{18}$. Materialne państwo prawne osadzone w personalizmie prawnonaturalnym odwołuje się do idei praw człowieka jako głównej zasady ustrojowej. Aspekt formalny państwa prawnego rozwijany w koncepcjach pozytywizmu prawniczego wyraża się w modus procedendi, technice funkcjonowania państwa na podstawie ustawowego porządku prawnego. Dyferencjacja ta mocno osadzona w prawoznawstwie wyznacza kontury najnowszej refleksji nad przedmiotem praworządności, który ewoluuje w stronę prymarności aspektu materialnego zgodnie z wnioskowaniem: skoro moralność jest przesłanką legalności, to moralność jest również przesłanką legalności prawa.

\section{PRAWORZĄDNOŚĆ JAKO DWUASPEKTOWA STRUKTURA AKSJOLOGICZNOPRAWNA}

\section{PRAWORZĄDNOŚĆ MATERIALNA VERSUS FORMALNA}

Prowadzone rozważania, z racji formy publikacji poddane zabiegom metodologicznym: uproszczenia, skrócenia i selekcji, w dalszym wywodzie odniesione zostaną do kwestii praworządności materialnej, czyli do jej aksjologicznych atrybutów, w myśl słów Horacego: quid leges sine moribus? - vanae proficiunt ${ }^{19}$. Praworządność materialna polega na obowiązku tworzenia, wykonywania i stosowania przez organy władzy publicznej takiego prawa, które spełnia łącznie dwa kryteria - wartości natury formalnej (lex) i wartości natury materialnej (ius) ${ }^{20}$. Immanenty związek, komplementarność owych kryteriów-wartości to jestestwo współczesnego demokratycznego państwa prawnego. Takie rozumienie prawo-

18 Wyrażenie Rechtsstaat jako pierwszy zastosował J.W. Placidus w pracy Literatur der Staatslehre - Ein Versuch, Strassburg 1798. Natomiast R. von Mohla uznaje się za pierwszego konceptualistę państwa prawnego, czemu dał wyraz w dziele Die Polizei-Wissenschaft nach dem Grundsätzen des Rechtsstaates, t. 1/2, Tübingen 1832/1833. Więcej na temat niemieckiej koncepcji Rechtsstaat zob. Z.A. Maciąg, Kształtowanie zasad państwa demokratycznego, prawnego i socjalnego w Niemczech (do 1949 r.), Białystok 1998; M. Zmierczak, Ksztaltowanie się koncepcji państwa prawnego (na przykładzie niemieckiej myśli polityczno-prawnej), [w:] Demokratyczne państwo prawne (aksjologia, struktura, funkcje). Studia i szkice, red. H. Rot, Wrocław 1992, s. 41 n.

19 Adagium horacjańskie pochodzące z pieśni Do zuchwałych bogaczy w thumaczeniu dosłownym brzmi: „,zym prawa bez obyczajów? — są puste”, a w eksplikacyjnym przekładzie prawniczym: „próżne i bezużyteczne są ustawy, jeżeli brakuje dobrych obyczajów”; M. Kuryłowicz, op. cit., s. 119.

20 Por. L. Morawski, Główne problemy współczesnej filozofii prawa. Prawo w toku przemian, Warszawa 2005, s. 317-327; J. Nowacki, Praworzadność, s. 80-93, 107-130; idem, Rzady prawa, s. 34-56. 
rządności wydaje się kończyć spór o to, czy mamy do czynienie z dwiema przeciwstawnymi koncepcjami państwa prawnego, materialną (niepozytywistyczną) i formalną (pozytywistyczną), czy też z jedną koncepcją o dwóch dopełniających się aspektach ${ }^{21}$. Argumenty proweniencji filozoficzno-historycznej przemawiają na rzecz ostatniej tezy. Koncepcja czystej praworządności formalnej rozwijana w skrajnych odmianach pozytywizmu, nawet nie tyle prawniczego, ile ustawowego $^{22}$, doprowadziła do nihilizmu aksjologicznoprawnego. W konsekwencji do narodzin epoki totalitaryzmów w postaci włoskiego faszyzmu, niemieckiego nazizmu, sowieckiego komunizmu i ich rodzimych wariantów w Chile, Hiszpanii, Argentynie czy Kubie. Pozytywistyczny znak równości między prawem a ustawą, tym samym apoteozę praworządności formalnej, najsilniej zanegował w 1946 roku G. Radbruch ideą sprawiedliwości w rozprawie Ustawowe bezprawie i ponadustawowe prawo ${ }^{23}$. Wspomniany rok można zatem uznać za datę odrodzenia się w europejskiej filozofii prawa nurtu prawnonaturalnego, a wraz z nim koncepcji praworządności materialnej.

Uwspółcześniona arystotelesowsko-tomistyczna koncepcja hylemorfizmu (gr. hyle - materia, morfe - forma) pozwala dostrzec relacyjny charakter stosunku materii do formy i recypować go na grunt rozważań filozoficznoprawnych. Forma nie jest przeciwieństwem materii (treści) i odwrotnie. Materia łączy się z podtrzymującą ją formą, a ta nadaje jej gatunkową właściwość. Są to więc współkonstytutywne elementy różnych rodzajów bytu, a wśród nich znajduje się prawo i wartość. Struktura bytowa prawa odznacza się relacyjnością prawa-uprawnienia (ius), czyli powinność (nie)działania do prawa-ustawy (lex), czyli do normy prawnej determinującej działanie, zachodzące między osobami ze względu na dobro wspólne będące celem osobowego działania ${ }^{24}$. Podobnie rzecz ma się z wartością pojmowaną jako relacja podmiotowo-przedmiotowa, a więc z takim bytem, który przez swoje właściwości obiektywnojakościowe, odpowiadające potrzebom psy-

21 Więcej o dyskusji krytycznej wokół praworządności formalnej i materialnej, w której te pojęcia ujmowane są zamiennie z pozytywistyczną i niepozytywistyczną koncepcją państwa prawnego, zob. L. Morawski, Spór o pojęcie państwa prawnego, „Państwo i Prawo” 1994, nr 4, s. 3-12. Głos polemiczny K. Działocha, W. Gromski, Niepozytywistyczna koncepcja państwa prawnego a Trybunat Konstytucyjny, „Państwo i Prawo” 1995, nr 3, s. 4-16.

22 Przez pozytywizm ustawowy rozumieć należy obowiązywalność każdej ustawy, nawet sprzecznej z podstawami-ideami prawa. Klasycy pozytywizmu prawniczego, zwłaszcza normatywista H. Kelsen, pojęcie prawa zredukowali do ustawy i utożsamiali państwo z prawem. W tym sensie każde państwo ze swej istoty było praworządne, skoro funkcjonowało na mocy ustawodawstwa (zob. H. Kelsen, Czysta teoria prawa, przeł. R. Szubert, Warszawa 2014). Rewizję tej koncepcji przeprowadzono w procesie norymberskim, dokonując oceny prawnej i moralnej ustawodawstwa III Rzeszy legalizującego ludobójstwo w imię praworządności formalnej, czyli rygorystycznego przestrzegania norm prawnych bez względu na ich treść, a tylko ze względu na prawomocne ich ustanowienie.

${ }^{23}$ G. Radbruch, Ustawowe bezprawie i ponadustawowe prawo, przeł. C. Tarnogórski, [w:] M. Szyszkowska, Zarys filozofii prawa, Białystok 2000, s. 256-266. Zob. także A. Szadok-Bratuń, Z dziejów teorii prawa natury w Polsce (1918-1989), Wrocław 2015, s. 53-56.

24 M.A. Krąpiec, Człowiek i prawo naturalne, Lublin 1975, s. 35. 
chofizycznym człowieka jest przez niego poznawczo pożądany ${ }^{25}$. Analogicznie do formy i materii istnieją wartości materialne i formalne, implikatywnie tak też istnieje dwuwartościowa praworządność. Ciąg przeprowadzonego wnioskowania wiedzie do konkluzji o relacyjnym charakterze stosunku między normami prawnymi (uzasadnionymi tetycznie) i normami moralnymi (uzasadnionymi aksjologicznie). W naturalnopersonalistycznej, niepozytywistycznej, koncepcji praworządności nie da się jednoznacznie oddzielić formalnego (prawnego) i materialnego (moralnego) aspektu prawa, gdyż są to, tak jak ius i lex, dwie strony tego samego zjawiska, jakim jest prawo.

\section{CZWÓRMIAN AKSJONORMATYWNY26}

W tym miejscu dyskursu pojawia się pytanie o sens wyczerpującej rekonstrukcji wartości przynależnych do praworządności o janusowym obliczu. Rozstrzygające znaczenie mają dwie konstatacje, obiektywna i subiektywna. Pierwsza — przeprowadzenie takiej rekonstrukcji wykracza poza ramy objętościowe szkicu, nadto byłaby to odtwórcza reduplikacja i kontaminacja rozlicznych autorskich katalogów występujących w obrębie pozytywistycznej i niepozytywistycznej koncepcji praworządności. Druga - w stosunku do przyjętych założeń badawczych zabieg taki wypada uznać za zbędny i wystarczy ograniczyć się do przytoczenia wartości materialnych najczęściej powtarzających się w wybranych źródłach prawa. Ponieważ praworządność materialna jest pojęciem inkluzywnym, łączącym atrybuty materialne i formalne, dlatego też nie może zabraknąć odwołania się do przykładowego katalogu wartości formalnych.

Amerykański filozof prawa jusnaturalista L.L. Fuller stworzył jeden z najbardziej znanych, powielanych i dopełnianych kanonów praworządności formalnej. Mówiąc językiem fullerowskim, sformułował listę zasad stanowiących minimum moralności wewnętrznej prawa utożsamianej z prawem naturalnym o charakterze formalnym ${ }^{27}$. Zasad gwarantujących realizację triady głównych idei juryspruden-

25 Zob. S. Kowalczyk, Człowiek w poszukiwaniu wartości. Elementy aksjologii personalistycz$n e j$, Lublin 2006, s. 133; A. Szadok-Bratuń, Krótkie rozważania o aksjologii, wartościach i antywartościach, [w:] Antywartości w prawie administracyjnym, red. A. Błaś, Warszawa 2016, s. 36-41.

26 Wyrażenie „czwórmian aksjologicznoprawny” zapożyczone zostało od Epikura z Listu do Menoikeusa. Desygnat tego pojęcia oznacza cztery zasady etyczne zwane czwórmianem terapeutycznym: „Bóg nie jest straszny; śmierci się nie odczuwa; to, co dobre, jest łatwe do zdobycia; to, co przykre, jest łatwe do zniesienia". Epikurejski tetrapharmakon (tetra - cztery, pharmakon lekarstwo) to zwrot metaforyczny oznaczający czteroczęściowy lek aplikowany w celu zniwelowania lęków w dążeniu do szczęśliwości człowieka. Zob. Diogenes Laertios, Żywoty i poglądy stynnych filozofów, Warszawa 1982, s. 643 n.

27 Fuller wyodrębnia dwie kategorie moralności, zewnętrzną i wewnętrzną, również dychotomicznie dzieli prawo na pozytywne i naturalne, a w obrębie tego ostatniego wyróżnia prawo formalne, tożsame z moralnością wewnętrzną prawa, oraz materialne, tożsame z moralnością zewnętrzną prawa. Tak więc kwestia relacji moralność a prawo sprowadzona zostaje do relacji prawo naturalne a prawo pozytywne. Jak spostrzega R. Tokarczyk, utożsamia on zewnętrzną i wewnętrzną moralność 
cji: celowości, procesualności i praktyczności w stanowieniu i stosowaniu reguł dobrego prawa. Autor wytypował osiem takich wymogów-wartości, przesądzających o moralności wewnętrznej porządku prawnego: 1. ogólność — prawo powinno istnieć, działać bezosobowo na podstawie norm uniwersalnych; 2. promulgacja - akty prawne powinny być podane do publicznej wiadomości, ogłaszanie gwarantem ich znajomości; 3. nieretroaktywność — prawo nie powinno działać wstecz, jest regulatorem prospektywnym nakierowanym na zachowania przyszłe, a nie przeszłe; 4. jasność — prawo powinno być zrozumiałe i spójne w swej treści; 5. niesprzeczność - prawo powinno być logiczne i niesprzeczne wewnętrznie; 6. możliwość wykonania - prawo nie powinno domagać się od adresata rzeczy niemożliwych; 7. trwałość — prawo nie powinno zmieniać się zbyt często, racjonalna stabilność; 8. zgodność - prawo stosowane w działaniach urzędowych powinno być zgodne z ogłoszonym ${ }^{28}$. Kanon tych klasycznych zasad umieszczony został w rozdziale o znamiennym tytule Moralność, dzięki której prawo jest możliwe; Fuller jasnym i prostym wywodem uzasadnia w nim przyjętą tezę: poszanowanie moralności wewnętrznej prawa (praworządności formalnej) prowadzi do poszanowania moralności zewnętrznej prawa (praworządności materialnej).

Nasuwa się zatem pytanie: $\mathrm{z}$ jakich medykamentów-postulatów powinien składać się dziś epikurejski tetrapharmakon terapeutyczny w odniesieniu do praworządności materialnej. Jeśli spojrzeć na źródła jurydyczne o zróżnicowanej proweniencji, począwszy od międzynarodowych przez unijne po rodzime, ustanawiające aksjologiczne katalogi zasad wpisanych w ontyczną strukturę prawodawstwa, to już prima facie widać ich zbieżność. Ograniczając ten akt poznawczy do mikrokomparatystyki, czyli do porównania przepisów-nośników wartości Konstytucji RP, Traktatu o Unii Europejskiej, w tym Karty praw podstawowych i Powszechnej deklaracji praw człowieka ${ }^{29}$, można wyprowadzić niejako przed nawias wspólne wartości dla owej triady aktów prawnych, takie jak: godność, wolność, równość i sprawiedliwość, uznając je umownie za czwórmianin aksjonormatywny.

2.1. Godność. Pierwszą wartością-normą stanowiącą oparcie praworządności materialnej jest pojęcie ,godności człowieka" ${ }^{30}$ wyartykułowane w preambule

prawa z prawem naturalnym, odpowiednio materialnym i formalnym; idem, Wstep, [w:] L.L. Fuller, Moralność prawa, przeł. S. Amsterdamski, Warszawa 2004, s. XV.

28 L.L. Fuller, op. cit., s. 38-80, 172-194. Por. J. Nowacki, Rzady prawa, s. 33-37.

29 Por. zestawienie wartości zawarte we wstępie Konstytucji RP z treścią art. 2 Traktatu o Unii Europejskiej i preambuły Karty praw podstawowych Unii Europejskiej (Dz.Urz. C 202 z 2016 r. wersje skonsolidowane Traktatu o Unii Europejskiej i Traktatu o funkcjonowaniu Unii Europejskiej wraz z Kartą praw podstawowych Unii Europejskiej) oraz z formułą aksjologiczną pomieszczoną $\mathrm{w}$ art. 1 Powszechnej deklaracji praw człowieka uchwalonej 10 grudnia 1948 r. przez Zgromadzenie Ogólne Narodów Zjednoczonych, http://amnesty.org.pl (dostęp: 27.01.2018).

30 W literaturze filozoficznoprawnej oprócz godności osobowej (kategoria ontyczna) wyróżnia się także godność osobowościową (kategoria empiryczna) określaną zamiennym terminem ,godność osobista". W pierwszym ujęciu godność jest trwała, absolutna, wrodzona i niezbywalna ze względu na 
i uszczegółowione w art. 30 Konstytucji RP. Aksjologia personalistyczna, a z taką mamy do czynienia zwłaszcza we wstępie do Konstytucji RP ${ }^{31}$, zakłada obiektywną hierarchię wartości, na której czele znajduje się dignitas hominis ${ }^{32}$. Odwołując się do myśli prosopoicznej ${ }^{33}$, godność należy rozumieć jako najbardziej prymarną wartość przysługującą każdej osobie pozostającej w relacjach interpersonalnych. Godność człowieka czyni z niego podmiot i cel działania, a nie przedmiot czy środek do celu. Treściowa eksplikacja tej zasady przybiera postać imperatywu praktycznego: „Postępuj tak, byś człowieczeństwa tak w twej osobie, jak też w osobie każdego innego używał zawsze zarazem jako celu, nigdy tylko jako środka" ${ }^{\text {34 }}$.

Godność jest przyrodzona, bo wypływa ze struktury bytowej człowieka i stanowi swoiste continuum trwania i ciągłości od urodzenia do śmierci, a więc jest niestopniowalna, nieredukowalna i nieprzenoszalna; jest niezależna od cech psychofizycznych osoby i sytuacji zewnętrznych. Dwuaspektowy przymiot niezbywalności oznacza niemożność utraty godności (wzmocnienia czy osłabienia) oraz jej zrzeczenia się wskutek działań podmiotu prawa i wolności. Kolejnym atrybutem godności jest jej nienaruszalność skorelowana z nieograniczalnością. Skoro ex definitione godność osoby jest „wartością wartości”, to w myśl fundamentalnej zasady personalizmu, czyli prymatu osoby nad społecznościami i rzeczami, nie istnieje taka kategoria dobra, interesu publicznego, która uzasadniałaby możliwość wkroczenia w sferę godności, gdyż jej źródło tkwi w prawnonaturalnej istocie osoby ludzkiej tożsamej z godnością. Spozytywizowanie, czyli wpisanie do Konstytucji RP zasady godności, wskazuje na przyjęcie przez prawodawcę ak-

fakt bycia człowiekiem. W drugim ujęciu godność jest zdobywana postępowaniem osoby pod wpływem dążenia do rozwoju własnej natury. Jest stopniowalna, bo można ją utracić, naruszyć, odebrać; względna, bo uwarunkowana miejscem człowieka w społeczeństwie i zależna od rasy, płci, kultury, społeczności i religii. Więcej na ten temat zob. A. Bronk, Kategoria godności człowieka w świetle hermeneutyki, „Analiza i Egzystencja” 2012, nr 19, s. 17; M. Piechowiak, Filozofia praw człowieka, Lublin 1999, s. 343-351; L. Garlicki, Komentarz do art. 30, [w:] Konstytucja Rzeczypospolitej Polskiej. Komentarz, red. L. Garlicki, M. Zubik, t. 2, Warszawa 2016, s. 28-29.

31 Alfabet Mazowieckiego, oprac. R. Graczyk „Tygodnik Powszechny” 2007, nr 16: „Preambuła do konstytucji z 1997 r. — tekst wymyślony przez Stefana Wilkanowicza i opublikowany pierwotnie w »Tygodniku Powszechnym« jako »Moja preambuła«, po modyfikacjach zgłoszony przez Mazowieckiego jako kompromisowa kompozycja. Zaakceptowany przez obie strony konfliktu, walnie przyczynił się do uchwalenia konstytucji”.

32 Pierwszym filozofującym prawnikiem, który przyznał godność wszystkim ludziom, niezależnie od ich miejsca pochodzenia i rangi społecznej, był Cyceron, który recypował od stoików pojęcie dostojności natury ludzkiej; A. Bronk, op. cit., s. 12.

33 Zob. więcej A. Szadok-Bratuń, M. Bratun, Personalizm filozoficzny a kultura prawa, [w:] Człowiek pomiędzy prawem a ekonomiq $w$ procesie integracji europejskiej, red. G. Dammacco, B. Sitek, O. Cabaj, Olsztyn-Bari 2008, s. 79-92 i cyt. literatura.

34 I. Kant, Uzasadnienie metafizyki moralności, przeł. M. Wartenberg, Warszawa 1984, s. 62. 
sjologii ius naturale 35 jako kontekstu jurydycznego powiązanego z podmiotowym statusem jednostki, jego prawami i wolnościami.

Zasada godności człowieka uzyskała charakter normatywny dopiero po II wojnie światowej, w dużej mierze za sprawą neotomisty J. Maritaina, współtwórcy deklaracji praw człowieka i orędownika jej niezwłocznego proklamowania. W swym dziele Les droits de l'homme et la loi naturelle wydanym w 1942 roku tak pisał: ,jest to rodzaj ewolucji intelektualnej i moralnej, która domaga się od nas, aby przywrócić filozofii prawdziwą naszą wiarę w godność osoby ludzkiej, w jej prawa, i aby odnaleźć autentyczne źródła tej wiary"36. Godność osobową można obecnie potraktować jako kategorię doktrynalno-prawno-orzeczniczą, której konotacja treściowa odnosi się do praw „godnościowoczłowieczych”37. Na jej wzór przedstawiciele personalizmu wypracowali pojęcie ,godności społecznej”. Zasada personacji społeczności ${ }^{38}$, oznaczająca tworzenie bytów multipersonalnych (stowarzyszenie, naród, państwo), w których wymiar strukturalno-normatywny miałby charakter podmiotowy, podkreślający osobowość społeczności, recypowana do porządku prawnego przybiera postać zasady godności społeczeństw, quasi-osób ${ }^{39}$. Ekstrapolacja pojęcia godności z osoby na społeczności pozwala konsekwentnie budować dwupersonalną koncepcję godności: osobowej i społecznej.

2.2. Wolność. Kolejną kategorią semantyczną i zarazem aksjonormatywną współkreującą katalog atrybutów praworządności materialnej jest pojęcie „wolności" ugruntowane w ustawie zasadniczej i w konstytucjonalizmie. W ujęciu filozoficznym wyróżnia się trzy podstawowe znaczenia wolności: ontyczne, em-

35 Ustrojodawca, respektując konstytucyjną funkcję integrującą naród, nie mógł spozytywizować konkretnej koncepcji prawa naturalnego. Musiał zachować neutralność, jak powiada, wobec wszystkich obywateli zarówno wierzących w Boga, jak i niepodzielających tej wiary. Zob. L. Garlicki, Komentarz do art. 30, s. 36-37. Więcej o klasyfikacji teorii prawa naturalnego zob. M. Szyszkowska, Teorie prawa natury XX wieku w Polsce, Warszawa 1982, s. 68-137; I.S. Grat, Stanowisko prawnonaturalne Czesława Strzeszewskiego na tle pogladów polskich tomistów, Białystok 2009, s. 15-164; A. Szadok-Bratuń, Z dziejów teorii prawa natury w Polsce (1918-1989), s. 86-114, $132-143$.

36 J. Maritain, Oeuvres complètes 1940-1963, Paris 1975, s. 202.

37 Zob. K. Complak, Stowo wstępne, [w:] Godność czlowieka jako kategoria prawa, red. K. Complak, Wrocław 2001, s. 6-7.

$38 \mathrm{~W}$ tradycji tomistycznej społeczność jest rozumiana jako uporządkowana jedność interpersonalnych relacji powstałych do osiągnięcia wspólnego dobra-celu. Elementem materialnym społeczeństwa są ludzie, a formalnym jedność: celów, środków, struktur i działań. Ludzką społeczność określał Akwinata mianem osoby ,jakby jednym człowiekiem” lub organizmu ,jakby jednym ciałem". Społeczność jest osobą moralnoprawną utworzoną do realizacji podstawowych wartości człowieka. Zob. S. Kowalczyk, Człowiek a społeczność, Lublin 2005, s. 222-223.

39 O zasadzie tej pisze S. Retterer w publikacji Pojęcie godności w obowiazującym i przyszłym prawie wspólnotowym w pracy zbiorowej pod red. K. Complaka (op. cit., s. 89-100). Autorka rozpatruje z perspektywy prawa unijnego nie tylko kwestie godności osobowej, ale również godności społecznej w odniesieniu do instytucji publicznych, dostrzegając jej dwuaspektową konstrukcję. Instytucjonalny aspekt godności obrazuje przykładem ochrony godności instytucji Europolu, a funkcjonalny — godności urzędu służby cywilnej. 
piryczne i aksjologicznormatywne ${ }^{40}$. Pierwsze akcentuje swobodę samookreślenia się osoby w aktach woli, czyli wolność wyboru (liberum arbitrium) określonego dobra uwarunkowanego aksjologią i prakseologią. Aspekt aksjologiczny to wolność wyboru między wartością a antywartością. Aspekt prakseologiczny z kolei to wolność polegająca na wyborze zarówno (nie)działania (libertas exercitii), jak i środków umożliwiających owo (nie)działanie (libertas specificationis). Drugie eksponuje swobodę samostanowienia osoby w wymiarze zewnętrznym (kreacji) i wewnętrznym (autokreacji). Wolność zewnętrzna, czyli „wolność od”, to wolność negatywna: brak ingerencji, represji lub przymusu. Wolność wewnętrzna, czyli „Wolność do”, to wolność pozytywna ukierunkowana na: dobro, piękno, prawdę czy sprawiedliwość ${ }^{41}$. Źródłem przyrodzonej wolności, tak jak godności, jest natura człowieka ukierunkowana na realizację pierwszej zasady prawa naturalnego (moralnego) wyrażonej w sądzie rozumu praktycznego: dobro należy czynić i go poszukiwać, a zła unikać. Zasada ta, będąc najzwięźlejszą ustawą promulgowaną w sposób naturalny w ludzkim rozumie (sumieniu), stanowi podstawę prawa pozytywnego, co implikatywnie oznacza przenikanie reguł z porządku moralnego (lex naturalis) do porządku prawnego (lex positiva) ${ }^{42}$.

Emanacją owych kategorii wolności jest wolność aksjologicznonormatywna (ujęcie trzecie), kładąca nacisk na uprawnienie i obowiązek osoby lub społeczności do (nie)podejmowania określonych zachowań ze względu na normy: moralne i prawne. Analogicznie do dwupostaciowej formuły godności oprócz wolności osobowej wyróżnia się wolność społeczną. Społeczność rozumiana jako wspólnota osób, więzi i celu jest wolna, o ile prawa regulujące jej działania nie zostały narzucone z zewnątrz (suwerenność zewnętrzna), lecz ustanowione w sposób demokratyczny przez nią samą (suwerenność wewnętrzna) ${ }^{43}$. Wyszczególnione kategorie wolności, powiązane konglomeratem praw i obowiązków, uwarunkowane są podwójnym typem odpowiedzialności etyczno-prawnej: odpowiedzialności „za” dokonane wybory i konsekwencje podjętych działań oraz odpowiedzialności „wobec" innych osób lub społeczności. W przeciwieństwie do godności nie istnieje wolność absolutna, skoro swoboda jednego bytu skorelowana jest ze swobodą drugiego. Determinizm ten polega na uznaniu prawa do wolności innych jednostek,

40 Zob. J. Herbut, Wolność. Leksykon filozofii klasycznej, red. J. Herbut, Lublin 1997, s. 541542; M. Piechowiak, Filozofia praw człowieka, s. 92-95, 280-286.

41 Zob. I. Berlin, Cztery eseje o wolności, przeł. D. Grinberg, D. Lachowska, J. Łoziński, Poznań 2000, s. 187-201.

42 Zob. C. Martyniak, Obiektywna podstawa prawa wedtug św. Tomasza z Akwinu, [w:] św. Tomasz z Akwinu, Dzieła, red. R. Charzyński, M. Wójcik, Lublin 2006, s. 97-144.

${ }^{43}$ Gwarantem wolności wewnętrznej państwa prawa jest demokratyczna forma rządów oparta na formalnych standardach-wartościach: 1 . ogólność i stabilność prawa; 2 . równowaga trójpodziału władz: legislatywy, egzekutywy i judykatywy; 3. parlament demokratycznie wybrany, zatwierdzający i odwołujący rząd; 4. decentralizacja stosunków ustrojowoprawnych; 5. sądowa kontrola aktów władzy; 6 . prawo do oporu w przypadkach nadużycia władzy. 
dlatego też konieczne są unormowania gwarantujące ochronę tego prawa, a także możliwość jego ograniczenia.

Filozoficzne koncepcje wolności przełożone, oczywiście niejednoznacznie, tylko analogicznie (jednoznaczność to właściwość poznania matematycznego), na język regulacji konstytucyjnych, symplifikując rzecz, wyrażone zostały w czterech formułach ${ }^{44}$. Pierwsza, wprowadzająca termin „prawo do wolności” współoznaczający desygnat szerszego pojęcia „prawa podmiotowe”, pojawia się wyłącznie we wstępie Konstytucji RP. Kategoria wolności aksjonormatywnej winna być pojmowana jako postulat prawa do wolności, ta modalność pokazuje, jak wartość wolności łączy się z wartością jurydyczności. Druga, konkretyzująca treść prawa do wolności, wyznacza w art. 31 ust. 3 granice ingerencji prawodawcy (klauzula limitacyjna) w sferę konstytucyjnych wolności i praw. Gwarantem przestrzegania prawa do wolności są organy władzy publicznej, na których spoczywa obowiązek stworzenia ram prawnych z jednej strony chroniących jednostkę przed naruszeniem jej wolności (instrumentarium pozytywne), z drugiej ograniczających możliwość wkraczania w sferę jej wolności bez konstytucyjnego uzasadnienia (instrumentarium negatywne). Trzecia, zakładająca ogólne rozumienie zasady wolności jako swobody podejmowania i wykonywania racjonalnych decyzji kierujących ludzkim postępowaniem (wolność wyboru i działania) i konieczność jej ochrony prawnej, pojawia się w art. 31 ust. 1 Konstytucji RP. Aksjonormatywna reguła wolności ma charakter uniwersalny, swym zakresem przedmiotowym obejmuje przestrzeń publiczną i prywatną, a podmiotowym trzy kategorie osób: osoby fizyczne, osoby prawne prawa prywatnego i osoby prawne prawa publicznego (wolność osobowa i społeczna). Czwarta, nawiązująca w konstrukcji prawnej art. 31 ust. 2 do filozoficznej idei wolności pozytywnej i negatywnej, nakazuje (wolność „do”) poszanowanie wolności i praw innych oraz zakazuje (wolność „od”) przymuszania do działań nienakazanych prawem.

2.3. Równość. Ustrojodawca kategorię „,równości” (gr. isotes, łac. aequitas) ${ }^{45}$, nieodłączny atrybut praworządności materialnej, uplasował w konstytucyjnym porządku wartości na trzecim miejscu, po godności i wolności, ujmując ją w kontury prawne art. 32 i przedsłowia. Ideę równości zwykło się wyprowadzać z tradycji demokracji ateńskiej i myśli arystotelesowskiej, niosących ponadczasowe rozróżnienia semantyczne, jak: równość wobec prawa, równość głosu, równość politycz-

44 Zob. L. Garlicki, K. Wojtyczek, Komentarz do art. 31, [w:] Konstytucja Rzeczypospolitej Polskiej. Komentarz, t. 2, s. 55-100; M. Piechowiak, Aksjologiczne postawy prawa, [w:] Synteza prawa polskiego od 1989 roku, red. T. Guz, J. Głuchowski, M.R. Pałubska, Warszawa 2013, s. 53, 57.

45 Równość oznacza relację zgodności między zbiorami różnych przedmiotów, osób, procesów lub okoliczności, które mają te same cechy co najmniej w jednym, ale nie we wszystkich aspektach, ponieważ równość to relacja podobieństwa, a nie identyczności; S. Gosepath, Equality, [w:] Stanford Encyclopedia of Philosophy 2007, https://plato.stanford.edu/entries/equality/ (dostęp: 26.01.2018). Por. W. Sadurski, Równość wobec prawa, „Państwo i Prawo” 1978, nr 8/9, s. 51-64. 
na, równość posiadania czy równość w prawach ${ }^{46}$. Stagiryta rozróżnił dwa rodzaje równości - arytmetyczną, przyznającą wszystkim ludziom te same prawa, i geometryczną, uwarunkowaną ich zdolnościami, wykształceniem, moralnością czy statusem społecznym, zwaną też zasadą proporcjonalności ${ }^{47}$. Rozumiał równość jako podobieństwo, a nie tożsamość i wiązał tę wartość ze sprawiedliwością, co wyraził słowami: „równość uchodzi za rzecz sprawiedliwą i jest nią istotnie, ale nie dla wszystkich, tylko dla równych; także nierówność uchodzi za sprawiedliwą, bo też jest nią rzeczywiście, lecz znów nie dla wszystkich, tylko dla nierównych"48.

Również nowożytna myśl oświeceniowa, zwłaszcza w osobie J.J. Rousseau, stanowiąca podglebie amerykańskiej i francuskiej deklaracji praw i wolności człowieka, dostrzegała równość natury ludzkiej i jej nierówność akcydentalną (przymioty psychofizyczne), co wiodło do przyznania wszystkim ludziom równości wobec prawa w wyniku umowy społecznej ${ }^{49}$. Współcześnie jurydyczną równość rozwijają koncepcje liberalizmu i personalizmu, w wielu kwestiach zbieżne, choć jednocześnie odmienne w swym ,genotypie”, oddziałując na aksjologię konstytucyjną. Liberalizm nie jest wyłącznie doktryną ekonomiczną, tak jak personalizm antropologiczną ${ }^{50}$, obie ujmują atrybut równości integralnie w wymiarze antropocentrycznym, społecznym, ekonomicznym i jurydycznym. Personalizm doprecyzował arystotelesowsko-tomaszową koncepcję człowieka osoby. W myśl tego stanowiska ludzie w porządku natury nie są sobie równi, albowiem każdy człowiek wyposażony jest przez nią w odmienne właściwości psychofizyczne. Inaczej jest w porządku osobowym (podmiotowym). Każdy człowiek niezależnie od wieku, płci, rasy, wykształcenia, wyznania jest równy, gdyż ma te same atrybuty: rozumność, wolność, autonomiczność, godność i podmiotowość prawną. Mimo iż cechy te podlegają zróżnicowanej aktualizacji ze względu na formy i fazy życia człowieka - są wspólne wszystkim ludziom ${ }^{51}$.

Aksjologiczna kategoria równości znajduje swe konstytucyjne odwzorowanie w dwóch zasadach — równości (art. 32 ust. 1) i niedyskryminacji (art. 32 ust. 2) ${ }^{52}$.

46 Zob. J. Bartyzel, Egalitaryzm, [w:] Powszechna encyklopedia filozofii, red. A. Maryniarczyk, t. 3, Lublin 2002, s. 20-22; S. Kowalczyk, op. cit., s. 181-196. Por. M. Piechowiak, Aksjologiczne podstawy prawa, s. 50-52; idem, Filozofia praw człowieka, s. 128-133.

47 Arystoteles, Etyka nikomachejska, V, 3, 1131 b; 4, 1132 a.

48 Arystoteles, Polityka, III, 5, 1280 a.

49 J.J. Rousseau, Umowa społeczna, przeł. A. Peretiatkowicz, Kęty 2002, s. 11, 19-20, 25.

50 Wypada zaznaczyć, iż personalizm nie musi być etykietowany: „można być chrześcijaninem i personalistą, racjonalistą i personalistą, komunistą; a czemu by nie? - i personalistą, jeśli jest się komunistą w sposób nie stojący w sprzeczności z podstawowymi wartościami”, E. Mounier, Co to jest personalizm?, przeł. D. Eska, A. Turowicz, A. Krasiński, Kraków 1960, s. 161.

51 Zob. M.A. Krąpiec, Ja - człowiek. Zarys antropologii filozoficznej, Lublin 1974, s. 380-388.

52 Konstytucja ekstrapoluje ogólną zasadę równości na konkretne sfery życia społecznego, np. równość: związków wyznaniowych (art. 25 ust. 1), kobiety i mężczyzny (art. 33); równy dostęp do: służby publicznej (art. 60), wykształcenia (art. 70 ust. 4). Więcej na temat zasady równości zob. L. Garlicki, M. Zubik, Komentarz do art. 31, [w:] Konstytucja Rzeczypospolitej Polskiej. Komentarz, 
Zasada równości przejawia się w dwóch wariantach semantycznych, odpowiednikach praworządności - równość w prawie, czyli w jego stanowieniu, i równość wobec prawa, czyli w jego stosowaniu. W pierwszym przypadku jej realizacja polega na tworzeniu takich treści prawa, by podmioty w podobnych sytuacjach były traktowane jednakowo (aspekt praworządności materialnej). W drugim - na jego stosowaniu przez władze publiczne wobec wszystkich adresatów uznanych za podobnych (aspekt praworządności formalnej). Realizacja równości wymaga zróżnicowanego potraktowania nierównych podmiotów prawnych, czy to osób fizycznych ze względu na status obywatela i cudzoziemca, czy to osób prawnych ze względu ich różnorodność zachodzącą nawet w tej samej kategorii.

Zasada niedyskryminacji związana z równością ochrony prawnej identycznie do zasady równości jest urzeczywistniania w obszarze stanowienia i stosowania prawa. Nadto ma charakter uniwersalny w ujęciu: podmiotowym - odnosi się zarówno do podmiotu prawa do niedyskryminacji, to jest osób fizycznych i prawnych, jak i do podmiotu obowiązku, wykonawcy tego prawa, to jest wszelkich organów władzy publicznej w sensie ustrojowym i funkcjonalnym, oraz przedmiotowym - odnosi się do sfery życia publicznego, społecznego lub gospodarczego.

2.4. Sprawiedliwość. Zarysowaną aksjologię praworządności materialnej niejako naturalnie uzupełnia kategoria sprawiedliwości, konstytuująca wespół z wcześniej omówionymi stabilny kanon wartości zrekonstruowany w obszarze konstytucyjnych norm ogólnych (wstęp i art. 2) oraz szczególnych związanych z prawem do sądu (art. 45 ust. 1, art. 175 ust. 1 i art. 177). Konstytucyjne umieszczenie sprawiedliwości między prawdą a dobrem i pięknem nie wydaje się słuszne, zważywszy na myśl filozoficzną antyku, w której wypracowano racjonalny, obiektywny i hierarchiczny porządek skłonności moralnych (cnót kardynalnych). Już w tradycji platońsko-arystotelesowskiej cnotę sprawiedliwości pojmowano jako zwieńczenie pozostałych cnót kardynalnych: mądrości, męstwa i umiarkowania kształtowanych intelektem nastawionym na poznanie prawdy, wolą - na pragnienie dobra, a obie władze zjednoczone na piękno ${ }^{53}$. $Z$ kolei umiejscowienie sprawiedliwości społecznej przed godnością, wolnością i równością jest wyrazem uznania zasady personalizacji społeczności ze względu na cel i charakter aktywności państwa prawnego. Uznania pierwszeństwa atrybutów wspólnoty państwowej przed atrybutami osobowymi ze względu na prawodawcę adresata obowiązku realizacji tej zasady. Sprawiedliwość ze swej istoty jest społeczna, ponieważ dotyka swą materią relacji wspólnotowych osoba-osoba, społeczność-społeczność 54 .

t. 2, s. 101-132; R. Balicki, M. Jabłoński, Komentarz do art. 31, [w:] Konstytucje Rzeczypospolitej oraz komentarz do Konstytucji RP z 1997 roku, red. J. Boć, Wrocław 1998, s. 71.

53 Por. M. Piechowiak, Komentarz do rozdziału I. Rzeczpospolita, uwagi 51-52, 94-99, [w:] Konstytucja RP, t. 1. Komentarz do art. 1-86.

54 Więcej o sprawiedliwości społecznej zob. P. Tuleja, Komentarz do art. 2, uwagi 72-105, [w:] Konstytucja RP, t. 1. Komentarz do art. 1-86. 
W ujęciu aretologicznym sprawiedliwość to zdolność do postępowania moralnego wobec siebie i innych zgodnie z normami etycznymi. Sprawiedliwość to „oddawanie każdemu tego, co mu się należy” (suum cuique tribuere) ${ }^{55}$. Tak brzmi jedna z najbardziej znanych i lapidarnych definicji sprawiedliwości sformułowana przez Platona i nieznacznie zmodyfikowana przez Ulpiana: „Sprawiedliwość jest stałą i niezmienną wolą przyznawania tego, co się komu należy"56. Platon teorię cnót odniósł do sfery społeczno-politycznej, uznając sprawiedliwość za cnotę-cel działania rządzących i rządzonych. Przyjmując za kryterium podziału dwa rodzaje równości: matematyczną i proporcjonalną, wyodrębnił identyczne formy sprawiedliwości: pierwsza zachodzi w relacjach międzyludzkich, a druga — między społecznością typu państwo a obywatelami.

Arystoteles, definiując sprawiedliwość jako jedyną spośród cnót będącą cudzym dobrem ${ }^{57}$, wyodrębnił trzy typy sprawiedliwości: wymienną (wyrównawczą), współdzielczą (kumutatywną) i rozdzielczą (dystrybutywną). Pierwsza z nich uwzględnia relacje osoba-osoba, opierając je, jak powiada K. Ajdukiewicz, na „zasadzie równej zapłaty i odpłaty”; innymi słowy za pracę należy się zapłata równa jej wartości, a za wyrządzoną szkodę — odpłata w postaci odszkodowania ${ }^{58}$. Druga wiąże się z przynależnością osoby do społeczności i miernikiem jej partycypacji w kreowaniu dobra wspólnego. Trzecia z kolei kształtuje relacje zwrotne między społecznością a osobą i odczytuje reguły obdzielenia jej członków tym, co wspólne (korzyści i ciężary) przy uwzględnieniu stopnia przyczynienia się do rozwoju wspólnoty. Sprawiedliwość rozdzielcza i współdzielcza opiera się na arystotelesowskiej „,zasadzie współmierności: nie po równo, ale proporcjonalnie” w stosunku do wiedzy, zasług, urodzenia czy zawodu ${ }^{59}$. Idea sprawiedliwości spokrewniona $\mathrm{z}$ ideą równości stanowi kwintesencję umiarkowanego nurtu egalitaryzmu, definiującego równość jako konieczność zróżnicowanego traktowania nierównych. Stanowisko to ilustrują dwa kolejne Ajdukiewiczowskie prawidła, stanowiące rdzeń poczucia sprawiedliwości, nazwane zasadą równej miary (,nikomu nie należy się nic z tego tylko tytułu, że to właśnie on, a nie kto inny") oraz zasadą równouprawnienia (,żadne wyjątkowe uprawnienia nie przysługują nikomu za to, co otrzymał w darze losu, a do czego sam się nie przyczynił. Wyjątkowe uprawnienia mogą przysługiwać ludziom tylko za to, co jest ich własnym działaniem") ${ }^{60}$. Ajdukiewicz formułę suum cuique ujął w trojakim sensie: komuś coś się należy ze względu na literę prawa pozytywnego, ducha tego prawa

55 Platon, Państwo, przeł. W. Witwicki, Warszawa 1958, I, 331.

56 Digesta justyniańskie. Księga pierwsza, przeł. B. Szolc-Nartowski, Warszawa 2007, 1, 1, $10 \mathrm{pr}$.

57 Arystoteles, Etyka nikomachejska, V, 1, 1130 a. Zob. Z. Pańpuch, Cnoty i wady, [w:] Powszechna encyklopedia filozofii, red. A. Maryniarczyk, t. 2, Lublin 2002, s. 225-229.

58 K. Ajdukiewicz, Język i poznanie, Warszawa 1985, s. 370.

59 J. Wojtysiak, Filozofia i życie, Kraków 2007, s. 221 n.

${ }^{60}$ K. Ajdukiewicz, op. cit., s. 372-375. 
i z powodu słuszności. W konsekwencji wyróżnił trzy pojęcia sprawiedliwości: 1. sprawiedliwość legalnej litery — każdy uczynek znajduje sankcję w prawie pozytywnym; 2 . sprawiedliwość legalnej zgodności z ideą prawa — prawo zawsze normuje pewien porządek społeczny, realizujący określony ideał, oddziałujący na ustawodawcę; 3. sprawiedliwość moralną — ocena ludzkich działań ze względu na podstawę słuszności przy użyciu przywołanych wyżej zasad. Epikeia, jak powiada Stagiryta, będąc korekturą prawa, dopełnia niedomagania sprawiedliwości ${ }^{61}$ i dyktuje sprzeciw wobec antynomii zachodzącej między literą prawa a jego ideą. Odwołuje się ona do sumienia, uczciwości, zdrowego rozsądku, jednym słowem do zasad prawa naturalnego, mając na uwadze dobro osobowe i wspólnotowe.

Wyłaniający się z przeprowadzonych analiz fragmentaryczny obraz aksjologizacji norm konstytucyjnych czy też odwrotnie jurydyzacji aksjologii został zaledwie naszkicowany. Aksjologia powiązana funkcjonalnie z konstytucjonalizmem, w tym z inspirującą, oryginalną i kreatywną interpretacją Trybunału Konstytucyjnego ${ }^{62}$, ma rozliczne walory kognitywne, eksplikatywne, prakseologiczne czy wręcz normatywne. Na gruncie polskiego prawoznawstwa staje się metodologicznym instrumentarium odczytywania prawa, potwierdzającego współistnienie aksjologii normatywnej z personalistyczną ideą praw człowieka interpretowaną w myśl klasycznej tradycji jako ius naturale i lex positiva.

\section{MINI REFLECTIONS ON MAXI ISSUES - ABOUT AXIOLOGICAL ASPECTS OF THE LAW AND ORDER}

\section{Summary}

The first part of the draft aims at presenting the law and order as a philosophical construct with regard to dichotomous divisions. The scope of the discourse has been reduced to two planes, also referred to as problems. The first, understanding the designations of opposition of such terms as eunomy - isonomy. The second, selective presentation of the opposing types of the law and order in the key of conceptual correlation: the law and order - legality, the subjective law and order - the objective law and order, the formal law and order — the material law and order.

The second part of the study is an attempt to understand the law and order in the optics of the axiological and legal binomial. Analogically to the first part of the publication, the methodological symmetry was maintained. The analyzes were made in two cognitive areas. The first is the

61 Arystoteles, Etyka nikomachejska, V, 10, 1130 b: „I to właśnie jest istotą prawości, że jest korekturą prawa tam, gdzie ono niedomaga na skutek ogólnego sformułowania”.

62 Więcej o konstytucyjnych wartościach w judykatach trybunalskich zob. L. Kieres, Orzecznictwo Trybunalu Konstytucyjnego wobec stanowiska ustawodawcy, [w:] Stan i kierunki rozwoju nauk administracyjnych, red. A. Błaś, J. Boć, Wrocław 2014, s. 53-68. 
definition of the material law and order understood in an inclusive way, including the attributes of the law and order. The second one is an attempt to select the principles-values from which the epicurean therapeutical tetrapharmacon should be composed in relation to the law and order.

Keywords: axiology of law, law and order, dignity, freedom, equality, justice, value

\section{BIBLIOGRAFIA}

Ajdukiewicz K., Język i poznanie, Warszawa 1985.

Arystoteles, Etyka nikomachejska, przeł. D. Gromska, Warszawa 2007.

Arystoteles, Polityka, przeł. L. Piotrowicz, Warszawa 2006.

Balicki R., Jabłoński M., Komentarz do art. 31, [w:] Konstytucje Rzeczypospolitej oraz komentarz do Konstytucji RP z 1997 roku, red. J. Boć, Wrocław 1998.

Banaszak B., Prawo konstytucyjne, Warszawa 2017.

Bartyzel J., Egalitaryzm, [w:] Powszechna encyklopedia filozofii, red. A. Maryniarczyk, t. 3, Lublin 2002.

Berlin I., Cztery eseje o wolności, przeł. D. Grinberg, D. Lachowska, J. Łoziński, Poznań 2000.

Bronk A., Kategoria godności człowieka w świetle hermeneutyki, „Analiza i Egzystencja” 2012, nr 19.

Complak K., Słowo wstęne, [w:] Godność człowieka jako kategoria prawa, red. K. Complak, Wrocław 2001.

Digesta justyniańskie. Księga pierwsza, przeł. B. Szolc-Nartowski, Warszawa 2007.

Diogenes Laertios, Żywoty i poglady stynnych filozofów, Warszawa 1982.

Działocha K., Gromski W., Niepozytywistyczna koncepcja państwa prawnego a Trybunat Konstytucyjny, „Państwo i Prawo” 1995, nr 3.

Garlicki L., Komentarz do art. 30, [w:] Konstytucja Rzeczypospolitej Polskiej. Komentarz, red. L. Garlicki, M. Zubik, t. 2, Warszawa 2016.

Garlicki L., Polskie prawo konstytucyjne. Zarys wyktadu, Warszawa 2014.

Garlicki L., Wojtyczek K., Komentarz do art. 31, [w:] Konstytucja Rzeczypospolitej Polskiej. Komentarz, red. L. Garlicki, M. Zubik, t. 2, Warszawa 2016.

Garlicki L., Zubik M., Komentarz do art. 31, [w:] Konstytucja Rzeczypospolitej Polskiej. Komentarz, red. L. Garlicki, M. Zubik, t. 2, Warszawa 2016.

Gosepath S., Equality, [w:] Stanford Encyclopedia of Philosophy 2007, https://plato.stanford.edu/ entries/equality/.

Górzyńska T., Zasada praworządności i legalności, [w:] Zasady podstawowe polskiej konstytucji, red. W. Sokolewicz, Warszawa 1998.

Graczyk R. oprac. Alfabet Mazowieckiego, „Tygodnik Powszechny” 2007, nr 16.

Grat I.S., Stanowisko prawnonaturalne Czestawa Strzeszewskiego na tle pogladów polskich tomistów, Białystok 2009.

Hayek F., The Constitution of Liberty, London 1976.

Herbut J., Wolność. Leksykon filozofii klasycznej, red. J. Herbut, Lublin 1997.

Kant I., Uzasadnienie metafizyki moralności, przeł. M. Wartenberg, Warszawa 1984.

Kelsen H., Czysta teoria prawa, przeł. R. Szubert, Warszawa 2014.

Kieres L., Orzecznictwo Trybunatu Konstytucyjnego wobec stanowiska ustawodawcy, [w:] Stan i kierunki rozwoju nauk administracyjnych, red. A. Błaś, J. Boć, Wrocław 2014.

Kołakowski L., Mini wykłady o maxi sprawach, Kraków 2003. 
Kopaliński W., Słownik mitów i tradycji kultury, Warszawa 1991.

Kopaliński W., Słownik wyrazów obcych i zwrotów obcojęzycznych, Warszawa 1967.

Kowalczyk S., Człowiek a społeczność, Lublin 2005.

Kowalczyk S., Człowiek w poszukiwaniu wartości. Elementy aksjologii personalistycznej, Lublin 2006.

Krąpiec M.A., Człowiek i prawo naturalne, Lublin 1975.

Krąpiec M.A., Ja - człowiek. Zarys antropologii filozoficznej, Lublin 1974.

Kuryłowicz M., Słownik terminów, zwrotów i sentencji prawniczych łacińskich oraz pochodzenia tacińskiego, Kraków 2002.

Langrod J., Instytucje prawa administracyjnego. Zarys części ogólnej, Kraków 2003, reprint.

Łętowska E., Pawłowski K., O prawie i o mitach, Warszawa 2013.

Maciąg Z.A., Ksztaltowanie zasad państwa demokratycznego, prawnego i socjalnego w Niemczech (do 1949 r.), Białystok 1998.

Mała encyklopedia kultury antycznej, red. Z. Piszczek, Warszawa 1968.

Maritain J., Oeuvres complètes 1940-1963, Paris 1975.

Martyniak C., Obiektywna podstawa prawa wedtug św. Tomasza z Akwinu, [w:] św. Tomasz z Akwinu, Dzieła, red. R. Charzyński, M. Wójcik, Lublin 2006.

Mohl R. von, Die Polizei-Wissenschaft nach dem Grundsätzen des Rechtsstaates, t. 1/2, Tübingen $1832 / 1833$.

Morawski L., Główne problemy współczesnej filozofii prawa. Prawo w toku przemian, Warszawa 2005.

Morawski L., Spór o pojęcie państwa prawnego, „Państwo i Prawo” 1994, nr 4.

Mounier E., Co to jest personalizm?, przeł. D. Eska, A. Turowicz, A. Krasiński, Kraków 1960.

Nowacki J., Praworzadność. Wybrane problemy teoretyczne, Warszawa 1977.

Nowacki J., Rzady prawa. Dwa problemy, Katowice 1995.

Pańpuch Z., Cnoty $i$ wady, [w:] Powszechna encyklopedia filozofii, red. A. Maryniarczyk, t. 2, Lublin 2002.

Piechowiak M., Aksjologiczne postawy prawa, [w:] Synteza prawa polskiego od 1989 roku, red. T. Guz, J. Głuchowski, M.R. Pałubska, Warszawa 2013.

Piechowiak M., Filozofia praw człowieka, Lublin 1999.

Piechowiak M., Komentarz do rozdziału I. Rzeczpospolita, uwagi 51-52, 94-99, [w:] Konstytucja $R P$, t. 1. Komentarz do art. 1-86, red. M. Safjan, L. Bosek, Warszawa 2016.

Placidus J., Literatur der Staatslehre — Ein Versuch, Strassburg 1798.

Platon, Państwo. Prawa (VII ksiag), przeł. W. Witwicki, Kęty 1998.

Prawo administracyjne, red. J. Boć, Wrocław 2010.

Radbruch G., Ustawowe bezprawie i ponadustawowe prawo, przeł. C. Tarnogórski, [w:] M. Szyszkowska, Zarys filozofii prawa, Białystok 2000.

Retterer S., Pojęcie godności w obowiąującym i przyszłym prawie wspólnotowym, [w:] Godność człowieka jako kategoria prawa, red. K. Complak, Wrocław 2001.

Rousseau J.J., Umowa społeczna, przeł. A. Peretiatkowicz, Kęty 2002.

Sadurski W., Równość wobec prawa, „Państwo i Prawo” 1978, nr 8/9.

Sarnecki P., Rzeczpospolita Polska państwem prawnym, [w:] Prawo konstytucyjne Rzeczpospolitej Polskiej, red. P. Sarnecki, Warszawa 2014.

Stownik łacińsko-polski, oprac. K. Kumaniecki, Warszawa 1973.

Sokolewicz W., Zubik M., Komentarz do art. 7, [w:] Konstytucja Rzeczypospolitej Polskiej. Komentarz, red. L. Garlicki, M. Zubik, t. 1, Warszawa 2016.

Szadok-Bratuń A., Krótkie rozważania o aksjologii, wartościach i antywartościach, [w:] Antywartości w prawie administracyjnym, red. A. Błaś, Warszawa 2016.

Szadok-Bratuń A., Z dziejów teorii prawa natury w Polsce (1918-1989), Wrocław 2015. 
Szadok-Bratuń A., Bratuń M., Personalizm filozoficzny a kultura prawa, [w:] Człowiek pomiędzy prawem a ekonomia w procesie integracji europejskiej, red. G. Dammacco, B. Sitek, O. Cabaj, Olsztyn-Bari 2008.

Szyszkowska M., Teorie prawa natury XX wieku w Polsce, Warszawa 1982.

Tokarczyk R., Wstęp, [w:] L.L. Fuller, Moralność prawa, przeł. S. Amsterdamski, Warszawa 2004.

Tuleja P., Komentarz do art. 2, uwagi 72-105, [w:] Konstytucja RP, t. 1. Komentarz do art. 1-86, red. M. Safjan, L. Bosek, Warszawa 2016.

Tuleja P., Komentarz do art. 7, uwagi 8-10, [w:] Konstytucja RP, t. 1. Komentarz do art. 1-86, red. M. Safjan, L. Bosek Warszawa 2016.

Wojtysiak J., Filozofia i życie, Kraków 2007.

Woroniecki J., Katolicka etyka wychowawcza, t. 1, Lublin 2013.

Wroczyński K., Praworządność, [w:] Powszechna encyklopedia filozofii, red. A. Maryniarczyk, t. 8, Lublin 2007.

Zimmermann J., Prawo administracyjne, Warszawa 2016.

Zmierczak M., Ksztaltowanie się koncepcji państwa prawnego (na przykładzie niemieckiej myśli polityczno-prawnej), [w:] Demokratyczne państwo prawne (aksjologia, struktura, funkcje). Studia i szkice, red. H. Rot, Wrocław 1992. 